УДК $638.15: 616.4$, DOI 10.31210/visnyk2018.04.35
(C) 2018

Назаренко О. С., аспірант

(науковий керівник - доктор ветеринарних наук, професор В. О. Свстаф'єва)

Полтавська державна аграрна академія

\title{
ВПЛИВ КЛІЩА VARROA DESTRUCTOR НА ПОКАЗНИКИ ГЕМОЛІМФИ МЕДОНОСНИХ БДЖІЛ
}

\section{Рецензент - кандидат ветеринарних наук О. В. Кручиненко}

Наведено результати експериментальних досліджень щзодо впливу збудника вароозу на кількісний склад формених елементів гемолімфи інвазованих бджіл з урахуванням їх вікових особливостей. Встановлено, щуо кількісні показники гемочитів у бджіл, уражених Varroa destructor, характеризуються зниженням відсотку пролейкоцитів (на 2,5-32,2\%) та зростанням відсотку нейтрофільних та еозинофільних фагоцитів (на 8,2-20,6\%). Кількість секреторних клітин сферулочитів у гемолімфі інвазованих бджіл змінювалася залежно від їх віку - знижувалася у бджіл одно- та дванадиятиденного віку (на 8,5 ma 4,9\%) i зростала у бджіл чотири- та восьмиденного віку (на 7,7 ma 16,6\%)

Ключові слова: Varroa destructor, варооз, медоносні бджоли, показники гемолімфи, вікова динаміка

Постановка проблеми. Аналіз клітинного складу гемолімфи має велике значення для оцінки фізіологічного стану бджіл. Це пов'язано 3 тим, що склад гемоцитів гемолімфи є непостійним і змінюється залежно від віку, сезону року, а також за різних захворюваннях та дії несприятливих факторів навколишнього середовища $[1,2$, 11].

Водночас, головною причиною порушень метаболізму хазяїна, що призводить до різкого зниження життєздатності усієї бджолиної сім’ї, $€$ значне збільшення чисельності популяції збудника вароозу [7].

Аналіз останніх досліджень i публікацій, у яких започатковано розв'язання проблеми. Дослідженнями вітчизняних вчених доведено, що варооз бджіл значно впливає на показники гемолімфи медоносних бджіл. Паразитування кліща Вароа призводить до зниження імунного статусу хазяїна, що супроводжується незначним збільшенням числа фагоцитів, зменшенням кількості сферулоцитів, а також слабкою активністю лізоциму і низькими титрами неспецифічних аглютинінів у гемолімфі інвазованих бджіл, що найбільш небезпечно для бджолиної сім'ї взимку $[8,12]$.

Також є наукові праці, в яких висвітлені пи- тання визначення змін у гемолімфі бджіл за використання різних препаратів (Апітонус, Біокант Плюс) та імуностимулюючих засобів (ехінацея, елеутерокок, ПДЕ - плацента денатурована емульгована) [4, 5].

Необхідно враховувати те, що склад гемолімфи бджіл $є$ непостійним і впродовж їх життя може відбуватися збільшення клітин фагоцитарного ряду, внаслідок накопичення чужорідних включень у процесі життєдіяльності бджоли і це може вважатися фізіологічним процесом [13].

За різних хвороб, зокрема інвазійних, важливим показником ефективної боротьби із захворюваннями $є$ зміни імунного статусу медоносної бджоли, до яких відносять показники гемолімфи. Гемолімфа, як кров тварин, максимально показує не тільки фізіологічні, але й патологічні зміни в організмі бджіл [3, 6, 9, 10, 13].

Отже, науково-практичний інтерес представляє вивчення впливу вароозної інвазії на організм медоносних бджіл з урахуванням їх віку.

У зв'язку з цим метою роботи було визначити впливу кліща Varroa destructor на склад гемолімфи інвазованих бджіл.

У завдання досліджень входило встановити склад гемоцитів у гемолімфі інвазованих бджіл різного віку; дослідити зміни імунного статусу хворих бджіл за показниками гемолімфи.

Матеріал і методи досліджень. Дослідження проводилися впродовж 2018 року на базі лабораторії кафедри паразитології та ветеринарносанітарної експертизи Полтавської державної аграрної академії, а також в умовах приватної пасіки Гребінківського району Полтавської області.

Об'єктом досліджень слугували бджоли однакового віку, яких отримували шляхом інкубації печатного розплоду в термостаті за температури $30 € \mathrm{C}$, вологості повітря 75-80\% та регулярного провітрювання. 3 рамки відбирали бджіл, які тільки вийшли 3 комірок, а також на 4-ий, 8-ий та 12-ий день після виходу з комірки.

Було сформовано 8 груп: 4 групи дослідні бджоли уражені кліщем Varroa destructor різного 
віку (одно-, чотири-, восьми- та дванадцятиденного віку) та 4 групи контрольні - бджоли вільні від кліща аналогічного віку.

3 кожної групи відбирали по 15 проб гемолімфи (всього 120 проб), з яких готували мазки, фарбували за Романовським-Гімза, фіксували етиловим спиртом. Використовували загальноприйняті методи мікроскопії та підрахунку на 100 клітин в одному мазку. Морфологічні характеристики гемоцитів оцінювали за О. В. Запольских [3]. Одночасно вираховували віковий коефіцієнт гемолімфи (ВКГ).

Отримані результати експериментальних досліджень обробляли статистично за допомогою комп'ютерної програми MS Excel 2003 шляхом визначення середнього арифметичного (M), його похибки (m) та рівня вірогідності (p) 3 використанням таблиці t-критеріїв Стьюдента (Мельниченко О. П., 2006).

Результати досліджень. За результатами про- ведених досліджень встановлено, що кліщі Varroa destructor значно впливають на фізіологічний стан інвазованих бджіл, а саме на показники їх гемолімфи. Так, у гемолімфі дослідних бджіл одноденного віку порівняно із контрольними знизилася кількість пролейкоцитів на 2,5\% $(67,60 \pm 0,56 \%, \mathrm{p}<0,05)$ і сферулоцитів на 8,5\% $(8,60 \pm 0,21 \%, \mathrm{p}<0,05)$, одночасно зросла кількість нейтрофільних фагоцитів на 20,6\% $(14,27 \pm 0,40 \%, \mathrm{p}<0,001)$ (рис. 1).

У дослідних бджіл чотириденного віку зрушення показників формених елементів були більш значнішими. Кількість пролейкоцитів продовжувала знижуватися до 47,13 $\pm 1,03 \%$ (на $16,0 \%, \mathrm{p}<0,001)$. Водночас зростала кількість нейтрофільних фагоцитів на $20,1 \% \quad(24,20 \pm 0,64 \%$, $\mathrm{p}<0,001)$, еозинофільних фагоцитів на $17,6 \%$ $(10,60 \pm 0,38 \%, \quad \mathrm{p}<0,001)$ та сферулоцитів на $16,6 \%(13,60 \pm 0,41 \%, \mathrm{p}<0,001)$ (рис. 2).

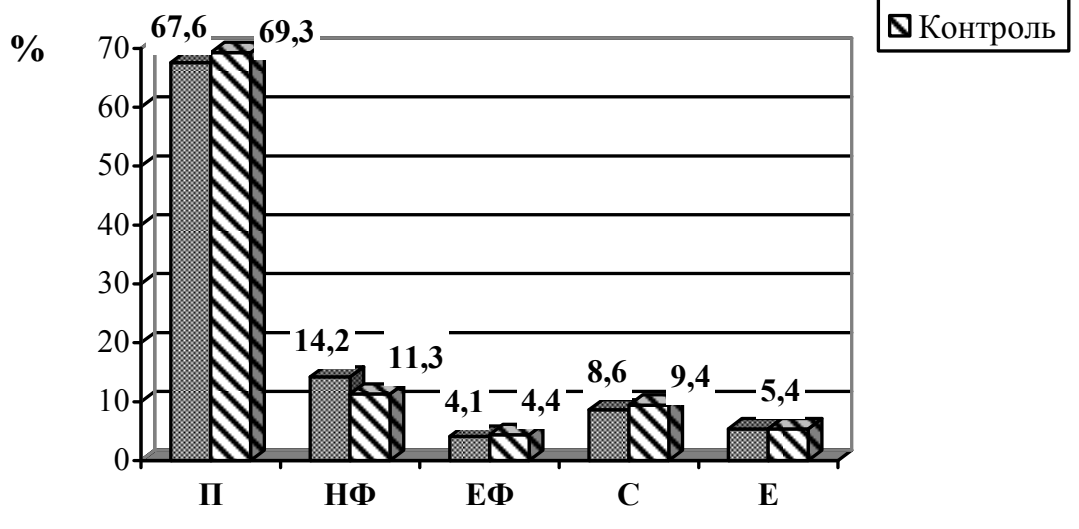

Рис. 1. Показники гемолімфи бджіл одноденного віку за вароозу: П - пролейкоцити, НФ - нейтрофільні фагоцити, ЕФ - еозинофільні фагоцити, C-сферулоцити, $E-$ еноцитоӥди

\%

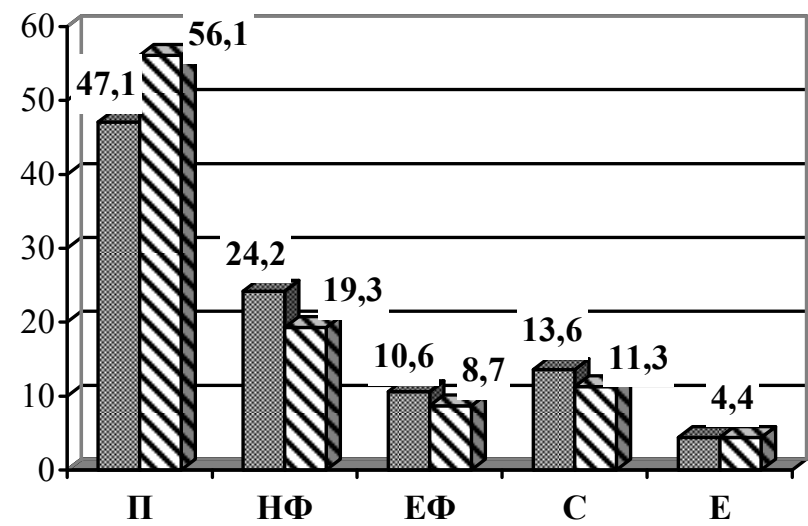
$\mathbf{\square}$ Дослід
$\mathbf{\nabla}$ Контроль

Рис. 2. Показники гемолімфи бджіл чотириденного віку за вароозу: П - пролейкоцити, НФ - нейтрофільні фагоцити, ЕФ - еозинофільні фагоцити, C-сферулоцити, $E-$-ноцитоӥди 
В інвазованих бджіл восьмиденного віку показники гемолімфи характеризувалися зниженням

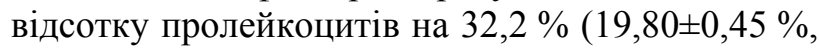
$\mathrm{p}<0,001)$, а також зростанням відсотку нейтрофільних фагоцитів на 20,1\% $\quad(29,40 \pm 0,40 \%$, $\mathrm{p}<0,001)$, еозинофільних фагоцитів на $13,1 \%$ $(21,40 \pm 0,38 \%, \mathrm{p}<0,001)$, сферулоцитів на 7,7\% $(25,20 \pm 0,24 \%, \mathrm{p}<0,01)$ (рис. 3$)$.

На дванадцятий день в гемолімфі бджіл, уражених кліщем $V$. Destructor, порівняно із неінвазованими бджолами, встановлено також зниження кількості пролейкоцитів на 21,6\%
$(14,80 \pm 0,17 \%, \mathrm{p}<0,001)$ і зростання нейтрофільних та еозинофільних фагоцитів на 8,2\% $(30,13 \pm 0,42 \%, \mathrm{p}<0,001)$ та $13,6 \%(24,53 \pm 0,34 \%$, $\mathrm{p}<0,001)$ відповідно. Однак відсоток сферулоцитів, порівняно із бджолами чотири- та восьмиденного віку, був зниженим на 4,9\% $(26,73 \pm 0,42 \%, \mathrm{p}<0,01$ проти контролю - 28,13 $\pm 0,27 \%$ (рис. 4).

Одночасно виявляли зміни і збоку показника ВКГ, який незалежно від віку дослідних бджіл достовірно $(\mathrm{p}<0,001)$ зростав впродовж експерименту (рис. 5).

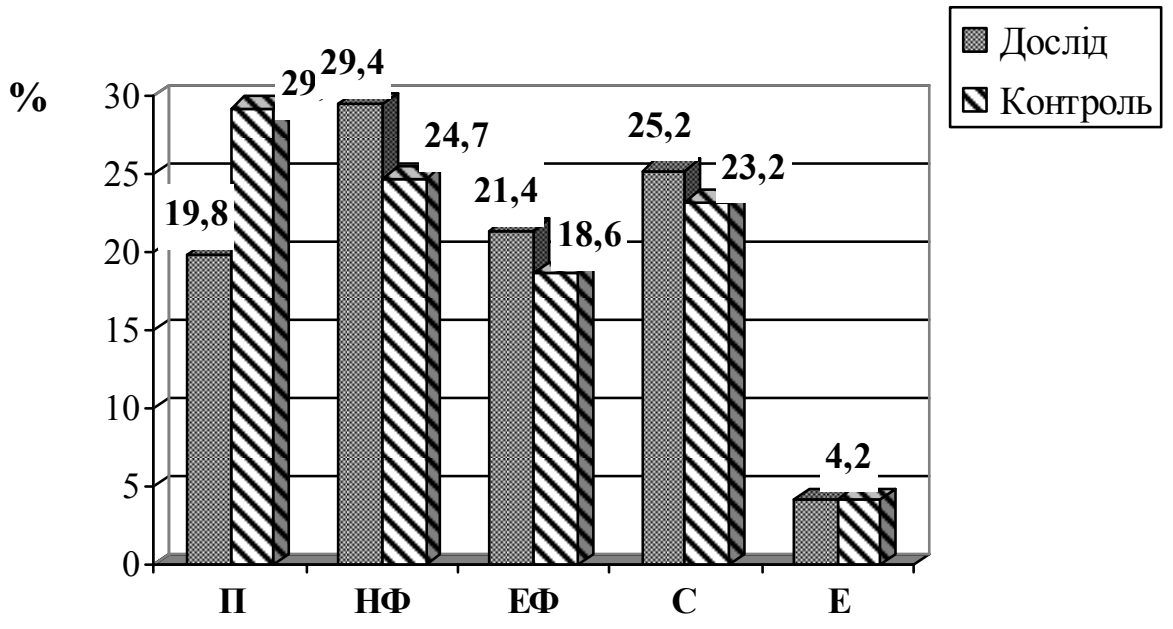

Рис. 3. Показники гемолімфи бджіл восьмиденного віку за вароозу: П - пролейкоцити, НФ - нейтрофільні фагоцити, ЕФ - еозинофільні фагоцити, C-сферулоцити, $E-$ еноцитоӥди

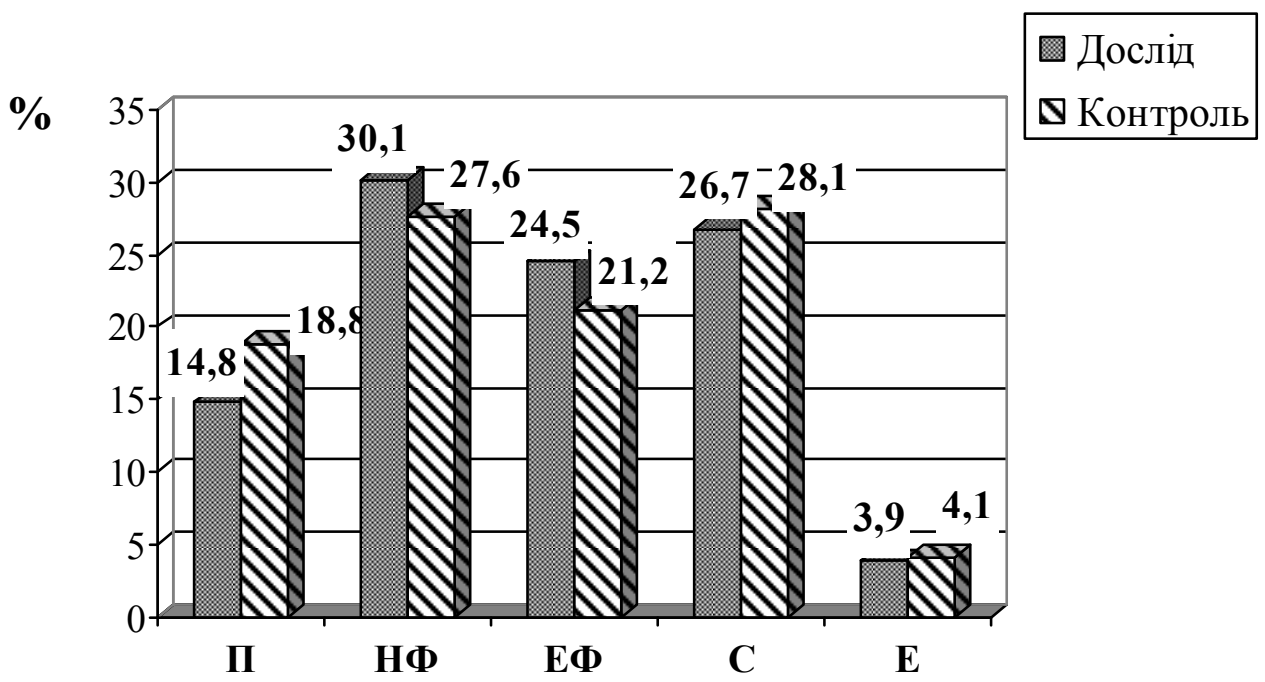

Рис. 4. Показники гемолімфи бджіл дванадцятиденного віку за вароозу:

П - пролейкоцити, НФ - нейтрофільні фагоцити, ЕФ - еозинофільні фагоцити, C-сферулоцити, $E-$-ноцитойди 


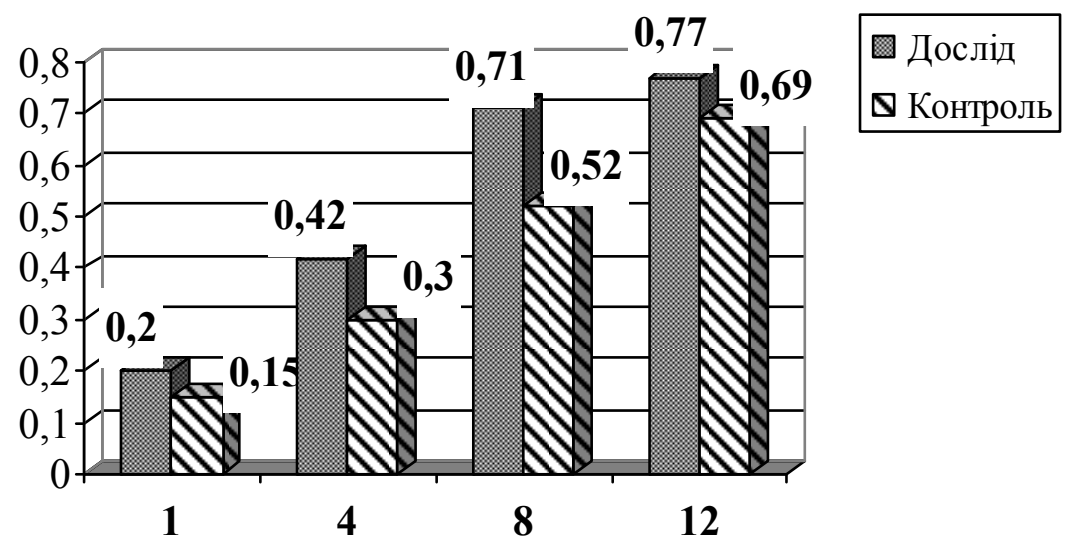

Вік

\section{Рис. 5. Динаміка показників ВКГ у бджіл різного віку за вароозу}

Так, у одноденних бджіл ВКГ становив $0,20 \pm 0,01$, що на $25,0 \%$ більше, ніж у контролі $(0,15 \pm 0,01)$.

У чотириденних дослідних бджіл ВКГ був більшим на $28,6 \%(0,42 \pm 0,02)$ порівняно 3 контролем $(0,30 \pm 0,01)$.

У дослідних бджіл у віці вісім днів порівняно 3 контрольними ВКГ зростав на $26,8 \%$, а у віці дванадцять діб - на 10,4 \%, що свідчить про виснаження клітинного імунітету інвазованих бджіл та може викликати скорочення їх життєздатність.

Отже, вароозна інвазія негативно впливає на фізіологічний стан бджіл про що свідчать зміни в показниках гемолімфи.

Збільшення кількості фагоцитів відбувається внаслідок імунної відповіді організму бджіл на патогенний фактор, а зменшення кількості пролейкоцитів вказує на поступове виснаження бджіл внаслідок інтоксикації продуктами життєдіяльності кліща.

Необхідно враховувати і те, що з віком бджіл вароозна інвазія прогресує, призводячи до зростання показника ВКГ та подальшого скорочення

\section{БІБЛІОГРАФІЯ}

1. Галатюк $О . \Phi$. Вивчення гемолімфи бджіл (аналіз та удосконалення виготовлення мазків гемолімфи): науково-практичні рекомендації / О. Ф. Галатюк, О. С. Кистерна, В. В. Гаркава, М. О. Володимирович. - Суми: СНАУ, 2015. $62 \mathrm{c}$.

2. Гробов О. Ф. Методика изучения гемолимформулы медоносной пчелы / О.Ф. Гробов // Системы введения пчеловодства в различных природно-климатических зонах. - М., 1968. C. $113-120$.

3. Запольських $O . B$. Морфологический и ци- терміну життєздатності бджолиної сім'ї в цілому.

\section{Висновки:}

1. Збудник вароозу Varroa destructor значно впливає на показники формених елементів гемолімфи інвазованих бджіл.

2. Інвазія проявляється зменшенням клітинпопередників - пролейкоцитів та зростанням фагоцитів, що свідчить про активізацію імунної системи бджіл, а також токсичну дію збудників інвазії.

3. Вік бджіл значно впливає на імунну відповідь бджіл за вароозу, про що свідчить динаміка секреторних клітин - сферулоцитів у гемолімфі бджіл.

4. Віковий коефіцієнт гемолімфи у бджіл за вароозу значно зростає (до 28,6 \%), що вказує на виснаження організму комах.

Перспективи подальшої роботи у даному напрямі. Перспективами подальших досліджень $\epsilon$ визначення впливу Varroa destructor на стан жирового тіла та тривалість життя медоносних бджіл.

тохимический анализ клеток гемолимфоформулы рабочей пчелы / О.В.Запольских // Цитология. - 1976. - № 8. - С. 956-962.

4. Кистерна О. С. Оцінка гемолімфи медоносних бджіл при використанні біологічних стимуляторів у лабораторних умовах / О. С. Кистерна, В. В. Гаркава, О. В. Мусієнко, В. М. Мусієнко // Вісник Сумського національного аграрного університету. Серія «Ветеринарна медицина». 2012. - Вип. 7. - С. 34-40.

5. Лукьянова Г. А. Влияние акарицидных препаратов растительного происхождения на клето- 
чный состав гемолимфы пчел / Г. А. Лукьянова, А. В. Перебийнис // Вісник Полтавської державної аграрної академії. - 2013. - № 3. - С. 123125.

6. Методы проведения научно-иследовательских работ в пчеловодстве / А. В. Бородачев, А. Н. Бурмистров, А. И. Касьянов [и др.] - Рыбное: НИИП, 2006. - 154 c.

7. Немкова С. М. Вплив паразитичного кліща Bapoa на медоносну бджолу Apis mellifera L., 1758 та шляхи його мінімізації в умовах України: автореф. дис. канд. біол. наук / С. М. Немкова. - Київ, 2003. - 20 с.

8. Немкова С. Н. Изменения биохимических показателей гемолимфы медоносной пчелы Apis mellifera L. (Hymenoptera, Apoidae), вызванные применением биологического препарата "Апитонус" для востановления физиологического состояния пчел, ослабленных паразитированием клещей рода Varroa Oudemans, 1904 / С. М. Немкова // Известие Харковського энтомологического общества. - X, 2001(2002). - Т. 10, Вып. 1-2. C. 324-326.

\section{ANNOTATION}

Nazarenko O. S. The effect of the Varroa destructor mite on hemolymph indicators of honey bees

Analysis of the cellular composition of hemolymph is of great importance for assessing the physiological state of the bees. This is due to the fact that the composition of hemocytes of the hemolymph is variable, which depends on the age, season of the year, as well as in various diseases and the impact of adverse environmental factors. Studies of domestic scientists have shown that varroosis of bees significantly affects the hemolymph indices of honeybees. A hemolymph like the blood of animals shows not only the physiological, but also the pathological changes in the body of the bees. So scientific and practical interest is the study of the effect of varooza invasion on the body of honey bees, taking into account their age.

In this connection, the purpose of the study was to determine the effect of the Varroa destructor mite on the composition of hemolymph of infested bees. The studies were being conducted during 2018 in the conditions of a private apiary in the Grebenkovsky district of the Poltava region. The object of the study were the bees of the same age, which were obtained by incubating of the printed brood. 8 groups were formed: 4 research groups which bees affected by the Varroa destructor mite of
9. Полтев В.И. Болезни и вредители пчел с основами микробиологии / В.И. Полтев, Е. В. Нешатаева. - М.: Колос, 1970. - 192 с.

10. Розанов Н. И. Микробиологическая диагностика заболеваний сельскохозяйственных животных: руководство для ветеринарных врачей диагностических лабораторий / Н. И. Розанов. М.: Сельхозгиз, 1952. -508 с.

11. Руденко E. В. Факторы гуморального иммунитета личинок пчел / Е. В. Руденко // Ветеринария. - 1990. - № 65.- С. 46-48.

12. Руденко $C$. В. Вплив вароотозної інвазії на клітинний склад гемолімфи та спроби його кореляції / Є. В. Руденко, І. Г. Маслій, С. М. Немкова // Вісник Сумського державного аграрного університету. Серія «Ветеринарна медицина». 2001. - Вип. 6. - С. 100-104.

13. Тушак С. Ф. Зміни кількісного складу гемолімфи у бджіл за використання препарату «Біоконтакт плюс» / С. Ф. Тушак, Т. О. Романишина, Ж. В. Рибачук, Л. Ф. Лемешинська // Біологія тварин. - 2018. - Т. 20, № 2. - С. 82-88.

different ages (one, four, eight and twelve days of age) and 4 control groups which bees were free from a mite of similar age.

From each group were taken 15 hemolymph samples (120 samples in total).

According to the results of the conducted research, it has been established that the Varroa destructor mites significantly affect the physiological state of the infested bees, namely, the indicators of the hemolymph formed elements. Invasion is revealed by a decrease in progenitor cells (proleukocyte and growth of phagocytes), which indicate the activation of the immune system of bees, as well as the toxic effect of invasion of pathogens. It has been proven that the age of bees has a significant effect on the bees' immune response to varroosis, as evidenced by the dynamics of secretory cells (the spherulites in bees hemolymph). It was found that the age ratio of hemolymph in bees over varroosis significantly increases (up to 28.6\%), which indicates the depletion of the insects' body.

Prospects for further research is to determine the effect of Varroa destructor on the state of the fat body and the lifespan of honeybees.

Key words: Varroa destructor, varroosis, honeybees, hemolymph indicators, age dynamics. 